Check for updates

The BMJ

Cite this as: BMJ 2021;375:n2554 http://dx.doi.org/10.1136/bmj.n2554 Published: 19 October 2021

\title{
Covid-19: Ministers told to reveal names of companies in "VIP lane" for PPE contracts
}

Gareth lacobucci

The UK's data privacy watchdog has ordered the government to reveal the names of almost 50 companies that were placed in the "VIP lane" to receive contracts to supply personal protective equipment during the covid-19 pandemic.

The Information Commissioner's Office issued the ruling after a complaint from the non-profit campaign group the Good Law Project that the Department of Health and Social Care for England had failed to comply with its request to disclose the names of the companies that received favourable treatment during the government's procurement of PPE.

On 18 October the information commissioner told the health department that it must publish the names of 47 companies within 35 calendar days. "Failure to comply may result in the Commissioner making written certification of this fact to the High Court pursuant to section 54 of the Act and may be dealt with as a contempt of court," the commissioner's letter said. ${ }^{1}$

The arrangement between the Cabinet Office and the health department that allowed some companies bidding for contracts to be channelled through a so called "VIP" or "high priority" lane because of their political connections has been heavily criticised by campaigners and the UK's public spending watchdog, the National Audit Office, for its lack of transparency. ${ }^{23}$

In her decision letter the information commissioner, Elizabeth Denham, wrote that because the health department had "not disclosed the requested information, nor advised the Commissioner that it considers it is otherwise exempt by virtue of another exemption," it had therefore "failed to comply with its obligations" under the Freedom of Information Act.

The Good Law Project, which has been pushing for greater transparency in the awarding of contracts for PPE and other areas during the pandemic, said it would publish the names of the 47 companies as soon as they are provided. Jo Maugham, the project's director, said, “Cronyism carries a double cost. It empties the public purse into the pockets of friends of the government. And it leads to bad outcomes for public health.

"The Good Law Project, which first revealed the existence of the VIP lanes for PPE and NHS Test and Trace, will continue the difficult but important work of exposing the truth around the government's sleazy pandemic procurement."

Earlier this year a High Court judge ruled that the UK government acted unlawfully in failing to publish details of dozens of contracts awarded without competition for goods and services such as PPE during the 19 pandemic. 4

The Department of Health and Social Care was approached for comment.

1 Information Commissioner's Office. Freedom of Information Act 2000 decision notice: reference IC-94513-N5H8 [redacted]. Oct 2021 https://drive.google.com/file/d/1BAvBbnviHY3UOKLAxcP1JbBXY4KNIqKD/view.

2 lacobucci G. Covid-19: One in five government contracts had signs of possible corruption, report finds. BM/2021;373:n1072. doi: 10.1136/bmj.n1072 pmid: 33893123

3 lacobucci G. Covid-19: Government has spent billions on contracts with little transparency, watchdog says. BMJ2020;371:m4474. doi: 10.1136/bmj.m4474 pmid: 33208349

4 Dyer C. Covid-19: Hancock's failure to publish contracts was unlawful. BMJ 2021;372:n511. doi: 10.1136/bmj.n511 pmid: 33608255

This article is made freely available for use in accordance with BMJ's website terms and conditions for the duration of the covid-19 pandemic or until otherwise determined by BMJ. You may use, download and print the article for any lawful, non-commercial purpose (including text and data mining) provided that all copyright notices and trade marks are retained. 